\title{
Constitutions in the European Union - Some Questions of Conflict and Convergence
}

\author{
Niilo Jääskinen
}

(C) ERA 2011

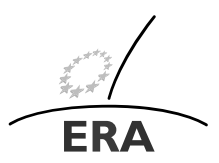

EUROPÄISCHE RECHTSAKADEMIE ACADEMY OF EUROPEAN LAW ACADEMIE DE DROIT EUROPEEN ACCADEMIA DI DIRITTO EUROPEO
TRIER - TREYES - TREYIRI

\begin{abstract}
The author explores two aspects of the relationship between the "constitution" of the EU and member states' constitutions - their potential for conflict, and possible elements of structural convergence. He considers the "constitutionalisation" of the EU as a starting point, as an on-going process, and as a desired result. The development of an autonomous institutional structure of the EU since the 1980s is presented, preliminarily culminating, after the failure of the Constitutional Treaty, in the explicitly non-statelike concept of the Lisbon Treaty. The author discusses the notion of "constitution" in a number of senses - formal vs. material, static vs. functional etc., and concludes that the potential conflict between the autonomy of EU law and the sovereignty of Member States is existential and cannot be resolved by legal means, which puts the national judge under a permanent challenge as he is obliged to serve two masters, EU law and national law. However, there is room for constructive coexistence of the two legal orders, and if considered as "non-momentary" constitutional systems "without an a priori claim of logical consistency" there is scope for mutual interaction - be it in a positive, "cross-fertilising", or a negative, intruding way, and even convergence.
\end{abstract}

Keywords EU · Member States · Constitution · Sovereignty · Autonomy · Conflict · Convergence

I want to thank Dr Pekka Aalto, my chef du cabinet, and Ms Liisa Holopainen, for their comments and help. The usual disclaimer applies.

N. Jääskinen $(\bowtie)$

Advocate General at the Court of Justice of the European Union, Luxemburg, Luxemburg

e-mail: niilo.jaaskinen@curia.europa.eu 
All constitutions of government, however, are valued only in proportion, as they tend to promote the happiness of those who live under them. This is their sole use and end. ${ }^{1}$

Adam Smith

\section{Introduction}

In 1997 Professor Jörg Gerkrath claimed that there is no European constitution, but that we live in an era of emerging European constitutional law. ${ }^{2}$ The political development of the European Union has proved the first part of that assertion, if we mean by a "constitution" a legal act that claims to be such. Yet the Treaty establishing a Constitution for Europe legally was only an international treaty between the Member States of the European Union, and not a proper "constitution".

What cannot be contested, however, is the emergence of European constitutional law. The emerging European constitutional law represents a fascinating field of interaction. Hundreds, perhaps thousands of articles and books have been devoted to the problems relating to the "constitutionalisation" of the European integration. Special attention has been paid to two aspects: the constitutional nature of the European Union legal order and its interaction with existing national constitutions.

In this contribution I shall explore two aspects: on the one hand I shall examine the conflicts between these systems, on the other hand I shall analyse their potential convergence from a structural point of view.

What I seek to show in this chapter is that the relationship between the EU constitution (independently of whatever form it has at any given moment) and the national constitutions of the Member States is tainted by an inevitable existential conflict in so far as they are understood as legal orders or momentary legal systems, i.e. systems of legal norms creating fields of consistent normative meaning. ${ }^{3}$ On the other hand, when we speak of them as legal systems in the sense of historically developing legal traditions without a claim of inherent internal consistency, their interaction presents itself as a multitude of contradictory, complementary or convergent paths of development. Therefore our understanding of the nature and potentialities of European constitutional law depends on our conceptual legal-theoretical commitments as to the nature of law in general. ${ }^{4}$

\footnotetext{
${ }^{1}$ Smith [24] Amazon Kindle version, location 3428, printed version, p. 275.

${ }^{2}$ Gerkrath [5], pp. 141-143.

${ }^{3}$ In Finnish legal theory a distinction has been made between a legal order as a system of legal norms, and a legal system as an intellectual construction embodying systematically construed concepts, theories, principles and doctrines. See e.g. Jääskinen [10], pp. 111-113. This distinction corresponds roughly with the difference J.W. Harris makes between a momentary legal system and a non-momentary or historical legal system. The momentary legal system in the sense of "present law" consists of all the mutually consistent legal rules understood as "pure norms" governing an area of human conduct at a particular moment. The legal science presupposes the existence of such a system, and it construes it by applying to the accepted legal sources the logical principles of legal science that are exclusion, subsumption, derogation and noncontradiction. For Harris, a non-momentary legal system refers to written choice-guidance devices like rules, principles, policies and maxims forming part of the tradition of a body of officials. See Harris [7], pp. 67-68, 111-115, 120-122.

${ }^{4}$ I add, for the sake of clarity, that these two ways of understanding law are not mutually exclusive, but that both are necessary. Moreover, in my opinion 'law' as a complex societal and cultural phenomenon
} 
The argument is organised as follows. The first two parts of the chapter will set out the threefold role of the constitutionalisation in the European polity and recall the pertinent characterisations of what is a "constitution". The core of the analysis focuses on the relation between primacy and sovereignty and how this "fundamental (non-)issue" has been addressed. This is followed by a brief section assessing the dichotomy between the concepts of cross-fertilisation and intrusion. The final part will then consider to what extent the European constitutional law affects the division of political power between different actors.

\section{Three Dimensions of the Constitutionalisation of the European Polity - Starting Point, Process and Desired Outcome}

Paradoxically, the constitutionalisation of the European Union legal order represents simultaneously a starting point, an on-going process and a desired outcome.

From the very beginning a constitutional interpretation was proposed as to the legal nature of the European integration within the framework of the "supranational" European communities. Constitutional nature referred to the idea of a legal order that is self-referring and autonomous in relation to international law and to national constitutions of the Member States. The Court of Justice adopted this interpretation, after some hesitation, and it guided as Leitmotiv its foundational judgments of 1960s and 1970s that established the leading principles of European Union law. ${ }^{5}$

The idea of constitutionalisation of European law as an emerging and on-going process was first noticed and described by an outsider, Professor Eric Stein from Michigan, who elegantly characterised the process with this famous phrase: "Tucked away in the fairyland Duchy of Luxembourg and blessed, until recently, with benign neglect by the powers that be and the mass media, the Court of Justice of the European Communities has fashioned a constitutional framework for a federal-type structure in Europe." 6

The re-launch of the integration project in the mid 1980s implied that also political actors - the institutions, Member States, lobbies and emerging European political parties - started to understand and debate in constitutional terms the developments expressed under headings such as "deepening of integration", "institutional reform", "democratic deficit", or "Europe of citizens". At the political level, this led to a succession of treaty reforms, starting from the Single European Act and ending, so far, in the Lisbon Treaty. At the academic level, the debate was no longer limited to experts of European law but also involved specialists of national constitutional law who previously had been relatively uninterested in the constitutional implications of the European construction.

can also be studied as a system of institutional behaviour or action or as a set of unconscious cultural and philosophical commitments defining the sphere of 'legal' as opposed to that of 'politics', 'moral' or 'economy'.

${ }^{5}$ Rasmussen [20].

${ }^{6}$ Stein [25]. 
Yet, Professor J.H.H. Weiler was right in stating in 2000 that "[i]f the objective is to open up the debate to a truly democratic, non court- and non elite-led constitutional discourse, then the need can be fully justified. But, if the objective is to increase the stability of the European order (and that is how it is typically presented) then the process might be counter-productive and yield the opposite: a decrease in stability."7

The negative outcomes of referenda relating to the Constitutional Treaty and the Lisbon Treaty have been understood as having revealed a lack of democratic legitimacy of the openly constitutional interpretation of the European integration. ${ }^{8}$ This is hardly surprising bearing in mind the intimate conceptual link that exists between the concept of constitution, on the one hand, and statehood and sovereignty on the other hand. In the political debate relating to constitutionalisation of European integration the final outcome, the finalité politique, of the European Union or "federal" Europe, has rarely been analysed and explicated in terms of statehood under international law even if the issue has been discussed in academic research. ${ }^{9}$

Therefore, the Constitutional Treaty, which deliberately used constitutional and state-like vocabulary, was seen by many voters as implying the emergence of a European federal state that would replace the nation state and threaten the emotional and democratic values it represents to its citizens. Even if the negative outcomes of the referenda in France and the Netherlands depended mainly on considerations relating to national politics, it cannot be denied that there is little popular support for a fully-fledged European federal state.

After the entry into force of the Lisbon Treaty, the European Union is a community of law with a constitutional charter that was expressly drafted as a "non-constitution" in spite of its contents that embody strengthened constitutional values in terms of protection of fundamental rights, division of powers and democratic accountability, among others. Simultaneously, the European Union has become more and more important as a frame of reference and as a problem for national constitutional law of the Member states.

\section{What Is a Constitution? ${ }^{10}$}

Constitution, like many related concepts such as federation, government or legislation, can be given (at least) two different interpretations, i.e. an institutional or

\footnotetext{
${ }^{7}$ Weiler [27], pp. 222-223.

${ }^{8}$ See IGC 2007 Mandate, Council of the European Union, 26 June 2007 11218/07 EN, p. 3: "The TEU and the Treaty on the Functioning of the Union will not have a constitutional character. The terminology used throughout the Treaties will reflect this change: the term "Constitution" will not be used, the "Union Minister for Foreign Affairs" will be called High Representative of the Union for Foreign Affairs and Security Policy and the denominations "law" and "framework law" will be abandoned, the existing denominations "regulations", "directives" and "decisions" being retained. Likewise, there will be no article in the amended Treaties mentioning the symbols of the EU such as the flag, the anthem or the motto. Concerning the primacy of EU law, the IGC will adopt a Declaration recalling the existing case law of the EU Court of Justice."

${ }^{9}$ See e.g. Mancini [18], pp. 51-66; Griller [6], pp. 35-42.

${ }^{10}$ This chapter builds on my article, Jääskinen [9], pp. 73-81.
} 
functional one or a state-dependent ("statist") one. Within the institutional framework such notions are used without implications concerning the nature of the polity concerned. From a statist point of view, these concepts are inherently linked to the concept of state. Hence, from an institutional point of view we can speak of the constitution of a non-state polity but a statist interpretation allows only (sovereign) states to have constitutions in the proper sense of the term.

Opting for an institutional or a statist understanding is heavily influenced by national traditions. In some legal cultures it is impossible to admit that a non-state actor could have a constitution because the notion is so "thick", i.e. it bears a plethora of connotations relating to the intellectual, constitutional and political history of that state. In other legal cultures the issue might be seen more as a question of terminology.

In legal terms ${ }^{11}$ a constitution refers to the rules and principles that constitute the organs of a political system and vest them with tasks and competences, regulate horizontal and vertical division of powers between them, define basic procedural principles applicable in enactment, execution and application of legal norms and define the boundaries of the autonomy of non-political actors in relation to political organs, especially the fundamental rights of individuals. In the continental doctrine a distinction is sometimes made between constitution in the formal sense and constitution in the material sense. ${ }^{12}$

Constitution in the formal sense refers to the enactment(s) ${ }^{13}$ that regulate issues mentioned above and has a special position in the legal system. Such enactments, often called basic or fundamental laws or simply constitutions or constitutional acts, are subject to different and more difficult amendment procedures than other laws. This may entail the use of qualified or super majorities, the requirement of a second reading by a new legislature or the attribution of constitutional powers (pouvoir constituant) to a different subject than ordinary legislative powers. Such constitutional legislator may be a separately elected constitutional convention or a combination of the legislature and the people expressing its will in a referendum. Moreover, constitutional enactments often possess superior rank in the hierarchy of legal norms in the polity, which is reflected as primacy in relation to ordinary laws.

Constitution in the material or substantive sense refers to the valid legal rules and principles, both statutory and conventional, which govern the constitutive issues mentioned above. A state has a constitution in the material sense even if it does not have one in the formal sense. The UK constitution is the best-known example of this. Polities with a constitution in the formal sense have, as a rule, a material constitution with a wider scope. This means that materially constitutional issues are also regulated

\footnotetext{
${ }^{11}$ In non-legal contexts there are both homonymic and metaphoric uses of the term 'constitution'. Thus we can speak of the physical 'constitution' of a young man or of the economic or social 'constitution' of a polity. As examples of the latter see e.g. Tuori [26], pp. 3-30 and Frerichs [4], pp. 69-88.

${ }^{12}$ See e.g. Griller [6], p. 29.

${ }^{13}$ A polity may have only a single constitutional enactment like Finland after 2000, a couple of them like Sweden or France, or the number of such acts may be quite high as in Austria. Some countries, like the United Kingdom, Israel and New Zealand do not have any constitutional enactments in the formal sense of the concept.
} 
by enactments of a lower hierarchical rank. Typical examples of this are the rules of procedure of the EU institutions.

Constitutions are linked to constitutionalism or the idea of a constitutional state, i.e. a polity where the exercise of political power is limited by predefined legal constraints that the polity imposes on itself by adopting a system of fundamental or higher rules governing the exercise of political power within its boundaries. In other words, the idea of constitutionalism is that the principle of legality or the rule of law also applies to the political system itself. From the perspective of history of ideas, the opposite of constitutionalism is despotism, i.e. a political system where political power is unlimited and it is exercised in the form of discretionary ad hoc decisions. Hence, constitutionalisation of the European Union means that as a polity the Union is, is becoming, or should be subject to predefined self-imposed legal constraints that cannot be altered by the Member States acting individually or collectively by following other courses of action than those provided by the constitution of the European Union itself, and within the limits provided therein.

Within the institutional or functional reading of constitution, the European Union can have, and actually has, a constitution in both the formal and material senses of the concept. ${ }^{14}$ As to the formal sense, the Court has characterised the Treaties as "constitutional charter of a Community based on the rule of Law". 15 They are legal acts regulating constitutional aspects ${ }^{16}$ of the EU having precedence over other EU legal acts and being subject to more stringent amendment procedures than ordinary EU legislation. However, if we adopt a statist reading of the concept of constitution, it is obvious that the European Union cannot have one since it lacks statehood under international law.

In the following I will use the concept of constitution understood in the institutional or functional sense, and thereby admit that the European Union already is a polity based on constitutionalism independently of its legal character as a sui generis community. This conceptual choice enables fruitful comparisons and juxtapositions between the EU constitution and Member States' constitutions.

\section{Primacy vs. Sovereignty - The Fundamental (Non-)issue?}

The basic theme of the constitutionalisation debate is the relation between primacy and autonomy of the EU and sovereignty of the Member States. During the 1950s the ECJ adopted, after some hesitations, a constitutional reading of Community law by regarding it as a system based on a foundational instrument, originally the ECSC Treaty that had to be interpreted autonomously and by paying primary attention to its objective purposes, not to the subjective intentions of the Member States as contracting parties. Consequently, a teleological and expansive approach to interpretation

\footnotetext{
${ }^{14}$ The same position is adopted, for example, by Griller [6], pp. 32-35; Rosas/Armati [22], pp. 1-5; and Lenaerts [15], p. 298.

${ }^{15}$ See Opinion of the Court 1/1991 [1991] ECR I-6079, paragraph 1; and judgment in C-294/83 Les Verts v Parliament [1996] ECR 1339, paragraph 23.

${ }^{16}$ It should be added that the Treaties include a plethora of provisions with non-constitutional content.
} 
was adopted instead of classical treaty interpretation or a method based on a comparative law approach seeking solutions common to the Member States' national legal orders.

This basic epistemological and methodological choice led to the great foundational judgments of the 1960s and 1970s establishing the principles of direct effect and primacy of Community law, protection of fundamental rights as an element of Community legal order, pre-emption of the Member States' competencies in the fields of exclusive or exercised Community competence, and, finally, damages liability of the Member States in cases of breach of EU law. The judgments created or revealed a legal system that was defined as "autonomous" both in relation to the national legal systems and to international law.

Depending on the basic legal theoretical commitments of the observer, this process can be seen as a creative and transformative exercise of judicial power by the ECJ, or as simply a discovery of law that somehow pre-existed before the constitutional judgments of the Court. Personally I have defended a view according to which the process can only be understood as a sequence of deliberate choices made by the ECJ, or more precisely outcomes of votes and deliberations by its members. Therefore a different path of case-law could have been chosen, which arguably would have led to a different institutional and constitutional development of the European integration, and to a different European Union, if any. ${ }^{17}$

Autonomy of EU law refers to its self-referential and homogeneous character. It has its own Kelsenian basic norm (Grundnorm) or Hartian Rule of Recognition. The validity and content of the legal norms and principles belonging to this legal order is defined solely by itself, i.e. by the constitution of the European Union. From this follows that not only the obligations of the Member States but also the legal position of individuals is defined by the EU law itself, not by national law, which explains the "existential" necessity of the principles of primacy and direct effect.

This conception of autonomy contradicts the notion of sovereignty in terms of constitutional and international law. Constitutionally sovereignty implies the capacity to decide which legal norms are valid in the territory of the state, and with which content. A state may exercise this "competence-competence" (Kompetenz-Kompetenz) by submitting itself to limitations or partial transfers of law-making powers to extrinsic organs but the power to revoke these restrictions remains in its sovereignty. From the international law point of view a state cannot modify its existing international obligations by means of its internal law, but it is up to the states to decide how they implement such obligations. Hence, the choice between a monist or dualist approach towards the internal effects of international law also is a matter of constitutional law of each state.

From the national law perspective there cannot be any law superior to the national constitution in the sense of the final norm-making power of Kompetenz-Kompetenz. Also in systems following the monistic principle it is up to the pouvoir constituant to modify or repeal this principle. Even if Hans Kelsen was wrong in stating that a state

${ }^{17}$ See Jääskinen [10], pp. 200-201. Rosas and Armati (Rosas/Amanti [22], p. 55) claim that the ECJ simply had to 'find' the primacy principle, otherwise the Communities would hardly been able to survive. 
is identical with its legal order, ${ }^{18}$ it would be difficult to deny that the legal existence of a sovereign state is defined by it having a separate self-referential constitutional order.

Autonomy of EU law and sovereignty of Member States' constitutional law creates the perspective of a fundamental conflict between these legal orders. The primacy of EU law, albeit not affecting the validity of national rules, anyhow requires that national judges refrain from applying any national rules that conflict with EU law. ${ }^{19}$ This obligation also concerns national norms of constitutional rank.

At a theoretical level such fundamental conflict resulting from this concomitant validity of the EU constitution and national constitutions at the territories of the Member States is in my view not resolvable with legal means. Its nature is existential. As Catherine Richmond has rightly pointed out, the choice as to the superiority of a legal system is epistemologically determined by the perspective of the observer, i.e. which ultimate rule defines the conditions of validity. ${ }^{20}$

Ultimate or fundamental conflict would be at hand between internal legality and European illegality of a measure, or vice versa. A topical example of the first case is the conflict between a national norm of superior rank and EU law; an example of the second would be a judgment of the ECJ recognising the EU having competence ultra vires. The possibility of such a fundamental conflict reflects radical legal theoretical pluralism as to the mutual relationship between these two autonomous orders. Unfortunately, the proposal of the late Neil MacCormick to find a legal solution to this conflict from a third legal order, namely international law, seems to me legally excluded ${ }^{21}$ and theoretically begging the question, as the solution would only extrapolate the problem to a universe of three autonomous legal orders. ${ }^{22}$

It is well known that national constitutional courts have been able to avoid the perspective of MAD or "Mutually Asserted Destruction" 23 inherent in the radical constitutional pluralism of the European construction by avoiding decisions that would have entailed a constitutional crisis relating to the position of EU law. They have wisely acknowledged that a state cannot continue to be a member of the EU without accepting the basic requirements of its constitution. In the recent doctrine there

\footnotetext{
${ }^{18}$ Kelsen [11], p. 192.

${ }^{19}$ Some authors use in this context terminology referring to the concept of normative hierarchy or rank. In my opinion it is misleading. That a rule has precedence of application does not entail that it is hierarchically superior, nor that it has a higher normative rank in relation to a norm of a different normative system. To claim that a provision of a technical directive is a 'higher' norm than a provision on fundamental rights in the constitution of a Member State represents, in my opinion, a similar categorical mistake as a claim that rules concerning the dosage of a medicine are higher norms than those concerning morality. Even if it is, in the treatment of a disease, more appropriate to apply the rules of legis arte of medicine than Immanuel Kant's categorical imperative, this does not follow from their superior hierarchical rank but from their appropriate scope of application.

${ }^{20}$ Richmond [21].

${ }^{21}$ As concerns EU law this is a question that falls within the exclusive jurisdiction of the ECJ. I fully share Weiler's argument that lacking legislative Komptenz-Kompetenz of the EU does not entail that its Court could not have, and that it actually has, judicial Kompetenz-Kompetenz as to the disputes concerning the limits of EU's powers. See Weiler [28].

${ }^{22}$ MacCormick [19], pp. 116-121.

${ }^{23}$ Weiler [28], pp. 320-321.
} 
have also been voices declaring the perspective of fundamental conflict as irrelevant because in ordinary legal life national courts recognise the superiority of EU law.

New mitigating approaches such as "multilevel constitutionalism", "Constitutionalism Beyond State" or "constitutional pluralism" have also been advanced as an alternative to the too rigid and monotonous understanding of the relationship between national and EU constitutions. ${ }^{24}$ Such newer approaches are built on the idea of a common network or texture of European constitutional law as a totality consisting of interacting systems that pay attention to and respect each other.

While fully admitting the limited practical relevance of the idea of radical separateness of EU law and national law as legal orders, it cannot be ignored for two reasons.

The first reason relates to the finalité politique of European integration. The autonomy of EU law as a legal order entails as a corollary the autonomy of the Member States' legal systems unless we adopt a view that the Member States' legal systems would be subsystems of EU law or that EU law and all national legal systems would be subsystems of a larger common European legal system. ${ }^{25}$ The latter two ideas would both entail a denial of Member States' sovereignty in terms of KompetezKompetenz, and consequently, their separate statehood represented as autonomous constitutional orders.

Yet it seems to me that both EU law and the Member States' constitutions are based on an assumption of the existence of the Member States as separate subjects vested with original and residual legislative, executive and judicial powers in all those fields where separate competences have not been attributed to the EU. Having said that, it becomes obvious that a shift from the Member States' statehood to a federal European statehood would represent a political choice that would be constitutionally excluded in most Member States without abandoning the existing basic constitutional principles.

The second and practically more important aspect relates to the normative asymmetry that is created by the existence of two autonomous orders. For the ECJ, the applicable law is EU law, and national law represents in most cases more a factual background than a normative constraint. For national courts, however, the situation is different. They are obliged to do something Hans Kelsen echoing Matthew ${ }^{26}$ considered impossible, namely to serve two masters, i.e. EU law and national law.

The national judge is faced with a legal reality where she has to apply two mutually independent but intertwined legal orders, paying due respect to the requirements of both. The primacy of EU law does not deprive her from the existential dependence

\footnotetext{
${ }^{24}$ These currents are represented, amongst others, by such scholars as Matej Avbelj, Jan Komárek, Matthias Kumm, Ingolf Pernice, Miguel Poiares Maduro, and Neil Walker. For their critique from a traditional Community law perspective, see Baquero Cruz [1], pp. 412-418; Louis [17], pp. 446-453. For a more sympathetic reading see Barents [2].

${ }^{25}$ This interpretation has been defended by Ines Weyland, see Weyland [29].

${ }^{26}$ Matthew 6:24, in King James Bible: "No man can serve two masters: for either he will hate the one, and love the other; or else he will hold to the one, and despise the other." See Kelsen [12], pp. 329-330 (supporting the claim that two valid systems of norms cannot conflict with each other).
} 
that binds her to the national constitution. Namely, she is a judge, a national judge, and consequently a European Union law judge with general jurisdiction, only as a result of the relevant provisions of national constitutional law. For her an obligation to apply and to give full effect to EU law cannot exist independently of the national constitution. Without it and its provisions validating EU law as a whole on national territory, EU law sources would be nothing more than pieces of paper for her. Hence, the existential duality of the European constitutional order and the irresolvable loyalty conflict remain acute for national judges.

In consequence, if we understand the EU constitution and national constitutions as (partial) legal orders or momentary legal systems, i.e. sets of legal norms constituting a consistent field of normative meaning, I find it obvious that a solution comprising both the unrestricted primacy of EU law, which is of an existential importance for EU law, and the sovereignty of Member States in the sense of constitutional KompetenzKompetenz is excluded. ${ }^{27}$ A national constitution can adapt itself to the principle of primacy of EU law in all other respects but not in relation to the secondary rules in the Hartian sense ${ }^{28}$ that relate to the constitutional identity of the Member State legal system. In the same way EU law may take into account national constitutions or seek inspiration from them but it cannot admit that national constitutions could limit the scope or contents of EU law. ${ }^{29}$

It should be added that this existential conflict is inevitable only in relation to the norms relating to the constitutional identity of the systems. In relation to any other question it is possible for the national legal systems to be Europeanised, i.e. to represent themselves as fields of consistent normative meaning including both relevant EU norms and national norms, mutually organised with a reference to the principles of primacy, direct effect and conform interpretation. ${ }^{30}$

In consequence, constitutional pluralism in the emerging common constitutional space of Europe can take place in a conceptual framework of constitutional law understood as composed of various historical legal systems in the sense of legal traditions, not in the sense of logically consistent sets of legal norms. In this perspective a legal system is understood as an evolving historical tradition embodying legal principles, policies, values and valuations that are "weight-bearing" and that lead to different directions. Therefore the application of a non-momentary legal system requires weighting or pondering, not subsumption.

In academic doctrine and judicial decision-making the role of the elements belonging to a non-momentary legal system relates to justification of interpretations of legal

${ }^{27}$ Griller rightly notes that the issue of Kompetenz-Kompetenz is not decisive as to the statehood of the EU because the crucial question is self determination in relation to other states, not how the constitutive power is distributed within the EU, Griller [6], pp. 37-39. This does not, however, apply to the level of Member States' constitution. For the Member States the loosing of their constitutional KompetenzKompetenz equals with loosing the right of self-determination and, a forteriori, independent statehood.

${ }^{28}$ I refer here to the rules of recognition, change and adjudication, see Hart [8], pp. 94-98.

${ }^{29}$ Here it is important to clarify that the validity of EU law as a whole is, of course, normatively dependent on the law of treaties and the Member States' constitutions. Without "a chain of validity" derived from these sources EU law would not have any legal effect whatsoever on the territories of the Member States. However, EU law is autonomous in the sense that it alone defines its contents, effects and the scope of any legal norm belonging to it.

${ }^{30}$ Jääskinen [10], pp. 154-158 and pp. 205-209. 
texts or choices between different incompatible norms. They are hence justificatory devices that are needed in order to end up in a deductively controllable exposition of the applicable legal rules. Legal systems as historical legal traditions neither are nor are presupposed to be logically consistent. In this respect they differ from legal orders or momentary legal systems that are represented as consistent sets of legal norms capable of acting as the major premise of a legal decision. ${ }^{31}$

In conclusion, in so far as we understand EU constitution and the national constitutions as legal orders, i.e. momentary systems of legal norms representing a field of consistent normative meaning, I do not see a possibility for constitutional pluralism: The EU constitution cannot renounce its claims of absolute primacy whereas the Member State constitutions cannot surrender their claim to constitutional KompetenzKompetenz. On the other hand, if and when we approach these systems of constitutional law as non-momentary historical legal traditions that include and embody a plethora of doctrines, principles, values and policies without an a priori claim of logical consistency, or even a claim of internal ideological coherence, it is obvious that these systems are capable of mutual interaction, even convergence or intertwinement.

\section{Cross-fertilisation vs. Intrusion}

The asymmetric nature of the mutual relationship between European constitutional law and national legal orders entails that the interaction between the two levels can be either cross-fertilisation or intrusion. By cross-fertilisation I mean the taking into account and making good of the contents of the other system for the purposes of one's own system, and by intrusion the unilateral and unwelcome constraint imposed by one system to another.

The capacity of the EU system to intrude in the national systems relates to its primacy, autonomy and obligation imposing character. The combination of primacy and autonomy entails that cross-fertilisation takes place in the direction from national systems to the EU system only to the extent and under the conditions determined by the EU system itself. However, the EU system encircles or imposes "encadrement" to national law also in fields where legislative competence remains at the national level. ${ }^{32}$

The ECJ has in innumerable cases stated that the issue at stake falls within the national competence but that competence has to be exercised by taking into account the requirements set by EU law. Therefore national competences cannot be used in a sovereign manner but within the framework of obligations imposed by the European order. The uneasiness created by ECJ case-law relating to, for instance, direct

\footnotetext{
${ }^{31}$ Bengoexthea, MacCormick and Moral Soriano speak of a process whereby the selected provision (major premise) is properly construed from an institutional standpoint into an applicable norm (the interpreted major premise, ready for application). See Bengoetxea/MacCormick/Moral Soriano [3], p. 57.

${ }^{32}$ See, for example, Lenaerts [14], pp. 1343-1375.
} 
taxation, ${ }^{33}$ social and health services, ${ }^{34}$ or more recently to names ${ }^{35}$ and to the acquisition and loss of national citizenship ${ }^{36}$ at the national level is explained by this figure of asymmetric interaction between the normative levels that to a certain extent blurs the effects of distribution of competences between the two orders.

However, it must be emphasised that the EU system has from the very beginning relied on inspiration sought from the Member States' systems to a much larger extent than was expressly provided in the treaties. ${ }^{37}$ The treaties originally referred to the principles of national law as a source of inspiration only in the case of non-contractual liability of the Communities, with the later addition of the common constitutional traditions of the Member States relating to fundamental rights. It also is obvious that European law has great influence on the development of the national constitutional law of the Member States, both at the level of constitutional legislation ${ }^{38}$ and at that of the case law of constitutional courts or other national courts exercising similar functions.

Common European constitutional law is created by a process of mutual interaction and debate seeking inspiration from the other European constitutional systems relating to issues such as the protection of fundamental rights, horizontal and vertical division of powers, judicial review and legal protection, the status of minorities, democracy and citizenship, only to mention the most pertinent examples.

\section{European Constitutional Law - A System of (Dis)empowerment?}

Constitutions are basically about power. Who has it and how should it be exercised? The constitutional relevance of European integration relates to this perspective.

A state acceding to the Union has to create internal constitutional conditions for EU membership, i.e. to ensure that the transfer of powers stemming from its Treaty of Accession is implemented at the level of internal constitutional law. This may require modification of the constitution or the application of a transfer of competence provision of the existing constitution. A state may also attempt to regulate the internal effects of EU law despite this being in principle futile because of the self-referential nature of the EU legal order. For national judges, however, it may be of paramount importance that the national constitution is adapted to the exigencies of EU law.

\footnotetext{
${ }^{33}$ See e.g. cases C-319/02 Manninen [2004] ECR I-7477; C-292/04 Meilicke and Others [2007] ECR I-1835; C-157/05 Holböck [2007] ECR I-4051; C-451/05 ELISA [2007] ECR I-8251; joined cases C-397/98 \& C-410/98 Metallgesellschaft and Others [2001] ECR I-1727; C-446/03 Marks \& Spencer [2005] ECR I-10837; C-196/04 Cadbury Schweppes et Cadbury Schweppes Overseas [2006] ECR I-7995; and C-524/04 Test Claimants in the Thin Cap Group Litigation [2007] ECR I-2107.

${ }^{34}$ See e.g. cases C-158/96 Kohll [1998] ECR I-1931; C-157/99 Smits and Peerbooms [2001] ECR I-5473; C-385/99 Müller-Fauré and van Riet [2003] ECR I-4509; C-372/04 Watts [2006] ECR I-4325; and C-287/05 Hendrix [2007] ECR I-6909.

${ }^{35}$ See e.g. cases C-148/02 Garcia Avello [2003] ECR I-11613; C-353/06 Grunkin and Paul [2008] ECR I-7639; C-208/09 Sayn-Wittgenstein [2010] ECR I-0000.

${ }^{36}$ See e.g. C-135/08 Rottmann [2010] ECR I-0000.

${ }^{37}$ Lenaerts/Gutiérrez-Fons [16], pp. 1633-1634.

${ }^{38}$ See Salminen [23], pp. 511-518.
} 
At the political level, EU membership leads to a shift of power in favour of the (central) government and the bureaucracies participating in the preparation and implementation of EU policies, at the expense of parliamentary and decentralised structures existing at the national level.

A striking feature of emerging European constitutional law is the development of counterbalancing structures subjecting national EU policy-making to parliamentary control and participation, usually in the form of a parliamentary European affairs committee scrutinising, at variable intensity, the EU decision making and the policies of the national government relating thereto. The informal cooperation between such committees under the auspices of COSAC, developed during the 1990s, has been included in the formal EU structures by the Lisbon Treaty. ${ }^{39}$ Broadly similar developments have taken place in relation to the role of regions and other sub-state actors in the European integration.

In so far as national constitutional and/or supreme courts are concerned, the EU's integration has both weakened and enhanced their position. The position of the ECJ as the supreme interpreter of EU law means that the interpretation of a huge part of the law of the land is no longer controlled by the traditional judicial structure but by an external judicial organ. However, the increased authority that follows from EU membership to the national judiciary in relation to the national executive and legislature compensates this new relation of dependency.

The primacy of EU law combined with the possibility to circumvent national power structures that is inherent in the preliminary ruling system has given national courts new authority and new de facto powers. Two examples of this phenomenon could be mentioned. The EU Factortame case law has given new prerogatives to the UK courts. In Finland the new Constitution that entered into force in 2000 rejected the traditional republican hostility vis-à-vis judicial review of the constitutionality of laws adopted by the Parliament. This had become obsolete because of the control of their compatibility with EU law necessitated by the principle of primacy of EU law.

What remains an open question is the position of the citizen, or more precisely the conceptualisation of European democracy. The case-law of the ECJ and the drafters of the Lisbon Treaty have been benevolent in inventing new rights for the citizen and broad avenues for democratic participation. Yet the citizen remains at best uninterested, and at worst hostile towards the development of a common European polity.

This shows the limits of constitutional law. A polity representing a feeling of common destiny cannot be created by law only. However, the common legal heritage of Europe is based on the assumption that without constitution and constitutionalism it is impossible to create a tolerable polity. Seen from this perspective it is perhaps preferable to have a Europe of many constitutions than a Europe with a single one.

\section{References}

1. Baquero Cruz, J.: The legacy of the Maastrich-Urteil and the pluralist movement. Eur. Law J. 14(4), 389-422 (2008)

${ }^{39}$ See, e.g. Kiiver [13], and the documentation on the COSAC site: http://www.cosac.eu/en/. 
2. Barents, R.: The Precedence of EU Law from the perspective of constitutional pluralism. Eur. Const. Law Rev. 5(3), 421-446 (2009)

3. Bengoetxea, J., MacCormick, N., Moral Soriano, L.: Integration and integrity in the legal reasoning of the European Court of Justice. In: De Búrca, G., Weiler, J.H.H. (eds.) The European Court of Justice, pp. 43-85. Oxford University Press, Oxford (2001)

4. Frerichs, S.: Constitutional ideal types in the global age: a sociological review. In: Tuori, K., Sankari, S. (eds.) The Many Constitutions of Europe, pp. 69-88. Ashgate (2010)

5. Gerkrath, J.: L'émergence d'un droit constitutionnelle pour l'Europe. Modes de formation et sources d'inspiration de la constitution des communautés et de l'Union européenne. Éditions de l'Université de Bruxelles, Brussels (1997)

6. Griller, S.: Is this a constitution? Remarks on a contested concept. In: Griller, S., Ziller, J. (eds.) The Lisbon Treaty: EU Constitutionalism without a Constitutional Treaty? pp. 21-56. Springer, New York (2008)

7. Harris, J.W.: Law and Legal Science. An Inquiry into the Concepts "Legal Rule" and "Legal System". Clarendon Press, Oxford (1979)

8. Hart, H.L.A.: The Concept of Law, 2nd edn. Oxford University Press, Oxford (1997)

9. Jääskinen, N.: Euroopan unionin konstituutio - perussopimus vai perustuslaki? [The constitution of the European Union - a treaty or a constitutional enactment?] In: Oikeustiede-Jurisprudentia XXXIV, pp. 67-153 (2001)

10. Jääskinen, N.: Eurooppalaistuvan oikeuden oikeusteoreettisia ongelmia [The europeanisation of law - jurisprudential problems]. Helsinki 2008

11. Kelsen, H.: General Theory of Law and State. Harvard University Press, Cambridge (1946)

12. Kelsen, H.: Reine Rechstlehre. Verlag Österreich, Viena (1960). Nachdruck (2000)

13. Kiiver, P.: The European constitution and the role of national parliaments: hard law language, soft content. In: Albi, A., Ziller, J. (eds.) The European Constitution and National Constitutions. Ratification and Beyond, pp. 223-234. Kluwer Law International, Dordrecht (2007)

14. Lenaerts, K.: Federalism and the rule of law: perspectives from the European Court of Justice. Fordham Int. Law J. 33(5), 1338-1387 (2010)

15. Lenaerts, K.: The basic constitutional charter of a community based on the rule of law. In: Poiares Maduro, M., Azoulai, L. (eds.) The Past and Future of EU Law. The Classics of EU Law Revisited on the 50th Anniversary of the Rome Treaty, pp. 295-315. Hart Publishing, Oxford (2010)

16. Lenaerts, K., Gutiérrez-Fons, J.A.: The constitutional allocation of powers and general principles of EU law. Common Mark. Law Rev. 47(6), 1629-1669 (2010)

17. Louis, J.-V.: La primauté du droit de l'Union, un concept dépassé. In: Chemins d'Europe, Mélanges en l'honneur de Jean-Paul Jacqué, pp. 443-461. Dalloz (2010)

18. Mancini, G.F.: Democracy and Constitutionalism in the European Union: Collected Essays. Hart Publishing, Oxford (2000)

19. MacCormick, N.: Questioning Sovereignty. Law, State and Nation in European Commonwealth. Oxford University Press, Oxford (2001)

20. Rasmussen, M.: The origins of a legal revolution: the early history of the European Court of Justice. J. Eur. Integr. Hist. 14(2), 77-98 (2008)

21. Richmond, C.: Preserving the identity crisis. Autonomy, system and sovereignty in European Law. In: MacCormick, N. (ed.) Constructing Legal Systems: 'European Union' in Legal Theory, pp. 47-90. Kluwer Academic, Dordrecht (1997)

22. Rosas, A., Armati, L.: EU Constitutional Law. An Introduction. Hart Publishing, Oxford (2010)

23. Salminen, J.: Manifestations of the European Union Membership in the Constitution of Finland References to the European Union in the Constitution of Finland in the European Context. Eur. Tidskr. Nr. 3, pp. 509-527 (2010)

24. Smith, A.: The Theory of Moral Sentiments, 2nd edn. Millar, Kincaid and Bell, London/Edinburgh (1761). Amazon Kindle Version; Printed version

25. Stein, E.: Lawyers, judges and the making of a transnational constitution. Am. J. Int. Law 75(1), 1-27 (1981)

26. Tuori, K.: The many constitutions of Europe. In: Tuori, K., Sankari, S. (eds.) The Many Constitutions of Europe, pp. 3-30. Ashgate (2010)

27. Weiler, J.H.H.: IGC 2000: The Constitutional Agenda. In: Best, E., Gray, M., Stubb, A. (eds.) Rethinking the European Union: IGC 2000 and Beyond, pp. 219-236. EIPA, Maastricht (2000)

28. Weiler, J.H.H.: The Constitution of Europe: "Do The New Clothes Have an Emperor?" and Other Essays on European Integration. Cambridge University Press, Cambridge (1999)

29. Weyland, I.: The application of Kelsen's theory of the legal system to European Community Law, the supremacy puzzle resolved. Law Phil. 1-37 (2002) 